\title{
PENGARUH TINGKAT PENDIDIKAN TERHADAP KEMISKINAN DI DKI JAKARTA
}

\author{
Oleh: \\ Rudy Susanto ${ }^{1}$ \\ Indah Pangesti ${ }^{2}$
}

\begin{abstract}
Fakultas Ilmu Pendidikan dan Pengetahuan Sosial
Universitas Indraprasta PGRI

E-Mail:

rudy.susanto19@gmail.com; esthicute@gmail.com
\end{abstract}

\begin{abstract}
This study aims to determine and analyze the influence of education on poverty level in Jakarta. The method used in this research is quantitative descriptive using secondary data from the Central Bureau of Statistics in 2014. Data analysis methods used chi-square analysis. The results showed that the level of education greatly affected poverty in DKI Jakarta. The lower the level of education, the higher the level of poverty and vice versa, the higher the level of education, the lower the level of poverty.
\end{abstract}

Keywords: Level of Education, Poverty Level

\begin{abstract}
ABSTRAK
Penelitian ini bertujuan untuk mengetahui dan menganalisis pengaruh tingkat pendidikan terhadap kemiskinan di DKI Jakarta. Metode penelitian yang digunakan dalam penelitian ini adalah deskriptif kuantitatif dengan menggunakan data sekunder dari Badan Pusat Statistik tahun 2014. Metode analisis data yang digunakan analisis chi kuadrat. Hasil penelitian menunjukkan bahwa tingkat pendidikan sangat mempengaruh kemiskinan di DKI Jakarta. Semakin rendah tingkat pendidikan maka semakin tinggi tingkat kemiskinan dan sebaliknya, semakin tinggi tingkat pendidikan maka semakin rendah tingkat kemiskinan.
\end{abstract}

Kata Kunci: Tingkat Pendidikan, Tingkat Kemiskinan 


\section{A. PENDAHULUAN}

Kemiskinan merupakan masalah klasik yang telah ada sejak menusia itu ada. Kemiskinan itu berwajah banyak dan akan terus menjadi persoalan dari masa ke masa, sehingga menjadi pusat perhatian pemerintah di negara manapun. Masalah kemiskinan merupakan salah satu persoalan mendasar, sehingga menjadi pusat perhatian pemerintah di negara manapun.

Nurkse (dalam Kuncoro, 2006) menggambarkan dalam teori lingkaran kemiskinan bahwa keterbelakangan, ketidaksempurnaan pasar, dan kurangnya modal dapat mengakibatkan rendahnya produktivitas manusia. Rendahnya produktivitas manusia akan mengakibatkan rendahnya pendapatan yang diterima. Rendahnya pendapatan yang diterima akan berakibat pada rendahya tabungan dan rendahnya investasi. Investasi bisa berupa investasi sumber daya manusia yaitu dengan ukuran pendidikan, maupun investasi kapital dengan ukuran konsumsi.

Berdasarkan teori lingkaran kemiskinan tersebut dapat diketahui ada beberapa faktor yang menyebabkan kemiskinan diantaranya tingkat pendapatan, tingkat pendidikan, dan besarnya konsumsi. Pengukuran kemiskinan yang dapat dipercaya dan kajian mengenai sebab-sebab kemiskinan menjadi instrumen tangguh bagi pengambil kebijakan dalam memfokuskan perhatian pada kondisi hidup orang miskin.

Pendidikan diakui secara luas bahwa memiliki peran sebagai pemimpin dalam instrumen pertumbuhan ekonomi. Oleh karena itu pendidikan semakin dikembangkan. Hal tersebut dilakukan karena pendidikan mampu memperbaiki kesejahteraan dan mengurangi kemiskinan (Bloom, 2006).

Pendidikan memiliki peran penting dalam mengurangi kemiskinan baik di Negara Indonesia atau negara manapun dalam jangka panjang. Baik secara tidak langsung melalui perbaikan produktivitas dan efisiensi secara umum, maupun secara langsung melalui pelatihan golongan miskin dengan keterampilan yang dibutuhkan untuk meningkatkan produktivitas mereka dan pada waktunya akan meningkatkan pendapatan mereka (Arsyad, 2010).

Pendidikan merupakan salah satu cara untuk meningkatkan kualitas sumber daya manusia. Melalui pendidikan, pengetahuan seseorang akan bertambah yang akan bermanfaat untuk mempelajari keterampilan yang berguna di dunia kerja. Dengan demikian pendidikan dapat dimasukkan sebagai investasi pembangunan yang hasilnya dapat dinikmati di kemudian hari. Sebagaimana pembangunan di bidang lain, pendidikan menjadi salah satu bidang utama selain kesehatan dan ekonomi.

Menurut Gillis (2000) terdapat dua alasan mengapa pendidikan itu penting. Pertama karena banyak permintaan yang tinggi untuk pendidikan, hal ini terjadi karena banyak masyarakat yang percaya bahwa pendidikan yang tinggi akan memberikan keuntungan bagi mereka. Kedua, karena banyak hasil observasi yang menyatakan bahwa dengan tingkat pendidikan yang tinggi maka pendapatan dan status sosial di masyarakat akan terangkat.

Untuk mengukur kemiskinan di Indonesia, Badan Pusat Statistik (BPS) menggunakan konsep kemampuan untuk memenuhi kebutuhan dasar (basic need approach). Dengan pendekatan ini kemiskinan dipandang sebagai ketidakmampuan dari sisi ekonomi untuk memenuhi kebutuhan dasar makanan 
dan bukan makanan (pakaian dan sebagainya) yang bersifat mendasar. "Penduduk miskin adalah penduduk yang memiliki rata-rata pengeluaran per orang (perkapita) per bulan di bawah garis kemiskinan." (Sukirno, 2006). Pengukuran kemiskinan dengan menggunakan konsep kemampuan memenuhi kebutuhan dasar tidak hanya digunakan oleh Badan Pusat Statistik (BPS), tetapi digunakan juga oleh negara-negara lain, seperti: Amerika, Pakistan, Bangladesh, Vietnam, dan Gambia. Bank Dunia mempunyai alat ukur kemiskinan dengan melihat kemampuan membeli (daya beli) US\$ 2 per hari.

Kemiskinan dapat juga dilihat dari dimensi lain, yakni tidak selalu dikaitkan dengan penghasilan atau konsumsi yang tidak cukup, namun dapat juga dilihat dari ketidakcukupan untuk kesehatan, nutrisi dan pendidikan. Dalam bidang pendidikan tingkat buta huruf dapat digunakan untuk mengukur garis kemiskinan. Indeks kesejahteraan komposif sebagai alternatif selain penggunaan dimensi tunggal, yakni dari aspek ekonomi semata-mata, dapat dilakukan kombinasi dari pengeluaran konsumsi (ekonomi), kesehatan dan pendidikan. Konkritnya mengkombinasikan penghasilan, kesehatan dan pendidikan.

Apabila data konsumsi, penghasilan atau data non moneter sudah didapat, maka akan ditetapkan garis kemiskinan. Garis kemiskinan adalah garis pemisah antara miskin dan tidak miskin. Perhitungan garis kemiskinan dapat dinyatakan dengan:

\section{GK = GKM + GKNM}

dimana:

GK $=$ Garis Kemiskinan

$\mathrm{GKM}=$ Nilai pengeluaran kebutuhan minimum makanan yang disetarakan dengan 2.100 kalori per orang per hari

GKNM = Kebutuhan minimum untuk perumahan, sandang, pendidikan dan kesehatan

\section{B. KAJIAN PUSTAKA}

\section{Kemiskinan}

Kemiskinan (poverty) masih menjadi salah satu fenomena sosial yang selalu ada di setiap negara berkembang, termasuk Indonesia. Indonesia merupakan salah satu negara berkembang yang memiliki permasalahan kemiskinan. Permasalahan kemiskinan merupakan permasalahan klasik yang kompleks dan bersifat multidimensional berwajah banyak dan akan terus menjadi persoalan dari masa ke masa. Kemiskinan merupakan masalah kompleks yang dipengaruhi oleh berbagai faktor yang saling berkaitan, antara lain: tingkat pendapatan, pendidikan, akses terhadap barang dan jasa, lokasi, geografis, gender dan kondisi lingkungan (Renggapratiwi, 2009).

Menurut Kuncoro (2006) Kemiskinan juga dapat didefinisikan sebagai "ketidakmampuan untuk memenuhi standar hidup minimum". Kebutuhankebutuhan dasar yang harus dipenuhi tersebut meliputi pangan, sandang, papan, pendidikan, dan kesehatan.

Kemiskinan adalah suatu kondisi kehidupan dimana terdapat sejumlah 
penduduk tidak mampu mendapatkan sumber daya yang cukup untuk memenuhi kebutuhan pokok (basic needs) minimum dan mereka hidup di bawah tingkat kebutuhan minimum tersebut. Sementera itu BPS dalam mengukur kemiskinan juga berdasarkan pada kebutuhan dasar (basic needs approach). Nilai kebutuhan dasar minimum tersebut digambarkan dengan garis kemiskinan.

\section{Teori - Teori Kemiskinan (Sukirno, 2006)}

\section{Teori Neo Liberal dari Shanon et. al}

Teori ini menjelaskan bahwa kemiskinan merupakan persoalan individual yang disebabkan oleh kelemahan dan pilihan individu yang bersangkutan. Kemiskinan akan hilang dengan sendirinya apabila kekuatan pasar diperluas sebesar-besarnya dan pertumbuhan ekonomi dipacu setinggi-tingginya. Cara menangani kemiskinan secara langsung melalui keluarga, kelompok swadaya atau lembaga keagamaan. Peran negara hanya sebagai penjaga yang baru boleh campur tangan apabila lembaga-lembaga tadi sudah tidak mampu lagi menjalankan tugasnya.

\section{Teori Sosial Demokrat}

Teori ini menganggap bahwa kemiskinan bukanlah persoalan individu tetapi persoalan struktural. Kemiskinan disebabkan adanya ketidak adilan dan ketimpangan dalam masyarakat akibat tersumbatnya akses kelompok kepada sumber-sumber kemasyarakatan terutama sumber ekonomi. Teori Sosial Demokrat menyarankan peranan pemerintah untuk menanggapi kemiskinan yang ada.

\section{Teori Marjinal dari Lewis}

Teori ini menganggap bahwa kemiskinan dinperkotaan terjadi disebabkan adanya kebudayaan kemiskinan yang tersosialisasi di kalangan masyarakat tertentu. Konsep Lewis yang terkenal mengatakan "Cuilture of Poverty". Menurut Lewis masyarakat di dunia menjadi miskin karena adanya budaya kemiskinan dengan karakter, apatis, kurang usaha, hanya menyerah pada nasib, sistem keuangan yang tidak mantap, kurang pendidikan, kurang mabisi untuk membangun masa depan, kesejahteraan dan kekerasan banyak terjadi.

\section{Teori Development (Teori Pembangunan)}

Teori ini muncul dari teori-teori ekonomi pembangunan terutama neo liberal yang menjelaskan kemiskinan terjadi karena persoalan ekonomi yang dianggap tidak adil.

\section{Teori Struktural}

Teori ini berdasarkan pemikiran yang berasal dari teori ketergantungan yang diperkenalkan oleh Andre Gunder Frank. Teori ini menyatakan bahwa kemiskinan terjadi bukan karena persoalan budaya dan pembangunan ekonomi, melainkan karena politik ekonomi dunia. 


\section{Pendidikan}

\section{Tingkat Pendidikan}

Pendidikan merupakan kebutuhan paling asasi bagi semua orang karena masyarakat yang berpendidikan setidaknya dapat memiliki kemampuan untuk membebaskan diri dari kemiskinan.

Menurut Ihsan (2011) tingkat pendidikan adalah tahap pendidikan yang bekelanjutan, yang ditetapkan berdasarkan perkembangan peserta didik, tingkat kerumitan bahan pengajaran dan cara menyajikan bahan pengajaran. Tingkat pendidikan sekolah terdiri dari pendidikan dasar, pendidikan menengah, dan pendidikan tinggi.

Tingkat pendidikan dapat digunakan sebagai salah satu indikator untuk melihat tingkat kesejahteraan penduduk. Semakin tinggi tingkat pendidikan seseorang, semakin baik pula kualitas sumber daya manusianya. Pendidikan sebagai faktor terpenting yang dapat membuat seseorang keluar dari kemiskinan. Keterkaitan kemiskinan dan pendidikan sangat besar karena pendidikan memberikan kemampuan untuk berkembang lewat penguasaan ilmu dan keterampilan (Suryawati, 2005).

\section{Manfaat Pendidikan}

Manusia adalah makhluk yang diciptakan Tuhan dengan memiliki sifat-sifat yang berbeda dengan makhluk lain yang hidup di dunia ini. Jika kita berbicara tentang pendidikan, manusia adalah sasaran pendidikan sekaligus subyek pendidikan.

Pendidikan membantu manusia dalam menumbuhkembangkan potensipotensi kemanusian yang ada dalam dirinya. Potensi kemanusiaan merupakan benih untuk mengembangkan seseorang menjadi manusia seutuhnya. (Nurihsan, 2007).

Tingkat pendidikan merupakan faktor penting yang mempengaruhi distribusi pendapatan dan kemiskinan. Psacharopoulos dalam Kokila (2000), telah menekankan peranan pendidikan di dalam pengurangan ketimpangan dan kemiskinan. Hal ini sejalan dengan Dejanvry dan Sadoulet dalam Kokila (2000) yang menyatakan bahwa pendidikan mengurangi ketimpangan dan kemiskinan secara langsung, yaitu: dengan meningkatkan produktivitas bagi golongan miskin, memperbaiki kesempatan mereka untuk memperoleh pekerjaan dengan upah yang lebih baik.

\section{Teori - Teori Tentang Pendidikan (Nurihsan, 2007).}

\section{Behaviorisme}

Asumsi filosofis dari Behaviorisme adalah nature of human being, yakni manusia tumbuh secara alami. Menurut faham ini, pengetahuan pada dasarnya diperoleh dari pengalaman. Aliran Behaviorisme berdasarkan pada perubahan tingkah laku yang dapat diamati. Oleh karena itu aliran ini berusaha menerangkan dalam pembelajaran bagaimana lingkungan berpengaruh terhadap perubahan tingkah laku. Dalam aliran ini tingkah laku dalam belajar akan bertambah jika ada stimulasus dan respon. Stimulus 
dapat berupa perilaku yang diberikan pada siswa, sedangkan respon berupa perubahan tingkah laku yang terjadi pada siswa. Jadi menurut teori Behaviorisme, pendidikan dipengaruhi oleh lingkungan. Tokoh aliran ini antara lain : Pavlov, Watson.

\section{Kognitivisme}

Teori pendidikan kognitivisme ini didasarkan atas rasional. Pengetahuan didapat dari pemikiran yang rasional. Menurut aliran ini kita belajar disebabkan oleh kemampuan kita dalam menafsirkan peristiwa atau kejadian yang terjadi dalam lingkungan. Oleh karena itu teori kognitivisme lebih menekankan pada proses belajar daripada hasil belajar itu sendiri. Tokoh aliran ini antara lain: Piaget, Bruner, dan Ausebel.

\section{Konstruktivisme}

Menurut teori ini yang menjadi dasar bahwa siswa memperoleh pengetahuan karena keaktivan siswa itu sendiri. Menurut teori kosntruktivisme, konsep pembelajaran adalah suatu proses pembelajaran yang mengkondisikan siswa untuk melakukan proses aktif membangun konsep baru dan pengetahuan baru berdasarkan data.

\section{Konsep Pembelajaran}

Dalam keseluruhan konsep pendidikan di sekolah, pembelajaran merupakan aktivitas yang paling utama. Ini berarti bahwa keberhasilan mencapai tujuan pendidikan banyak bergantung pada bagaimana proses pembelajaran dapat berlangsung secara efektif. Institusi pendidikan harus dapat menyelenggarakan proses pembelajaran berlangsung dengan efektif. Menurut UNESCO proses pembelajaran yang efektif itu bertumpu pada empat pilar, yaitu : learning to know, learning to do, learning to be, learning to live together.

\section{METODE PENELITIAN}

\section{Jenis dan Sumber Data}

Data yang digunakan penelitian ini adalah data sekunder yang diperoleh dari Badan Pusat Statistik (BPS) data tahun 2014.

\section{Variabel Penelitian}

Variabel yang diperlukan dalam penelitian ini adalah :

1. Tingkat Pendidikan.

2. Kemiskinan di DKI Jakarta.

\section{Desain Penelitian}

Penelitian ini bersifat kuantitatif. Untuk melihat pengaruh dua set (dua himpunan) yang anggotanya tingkat pendidikan, yakni : SD, SMP, dan SMA +, terhadap tingkat kemiskinan di enam daerah ibukota DKI Jakarta disusun matriks 
yang terdiri atas baris dan kolom. Barisnya ada tiga yakni tingkat pendidikan, sedangkan kolomnya ada enam yakni enam daerah DKI Jakarta, seperti tampak pada tabel berikut:

Tabel 1. Matriks Data

\begin{tabular}{|c|c|c|c|c|c|c|c|}
\cline { 2 - 7 } \multicolumn{1}{c|}{} & $\mathrm{X}_{1}$ & $\mathrm{X}_{2}$ & $\mathrm{X}_{3}$ & $\mathrm{X}_{4}$ & $\mathrm{X}_{5}$ & $\mathrm{X}_{6}$ & Jumlah \\
\hline $\mathrm{X}_{1}$ & $\mathrm{X}_{11}$ & $\mathrm{X}_{12}$ & $\mathrm{X}_{13}$ & $\mathrm{X}_{14}$ & $\mathrm{X}_{15}$ & $\mathrm{X}_{16}$ & $\sum \mathrm{X}_{1 \mathrm{j}}$ \\
\hline $\mathrm{X}_{2}$ & $\mathrm{X}_{21}$ & $\mathrm{X}_{22}$ & $\mathrm{X}_{23}$ & $\mathrm{X}_{24}$ & $\mathrm{X}_{25}$ & $\mathrm{X}_{26}$ & $\sum \mathrm{X}_{2 \mathrm{j}}$ \\
\hline $\mathrm{X}_{3}$ & $\mathrm{X}_{31}$ & $\mathrm{X}_{32}$ & $\mathrm{X}_{33}$ & $\mathrm{X}_{34}$ & $\mathrm{X}_{35}$ & $\mathrm{X}_{36}$ & $\sum \mathrm{X}_{3 \mathrm{j}}$ \\
\hline Jumlah & $\mathrm{X}_{\mathrm{i} 1}$ & $\mathrm{X}_{\mathrm{i} 2}$ & $\mathrm{X}_{\mathrm{i} 3}$ & $\mathrm{X}_{\mathrm{i} 4}$ & $\mathrm{X}_{\mathrm{i} 5}$ & $\mathrm{X}_{\mathrm{i} 6}$ & \multicolumn{1}{c}{} \\
\cline { 1 - 7 } & & \multicolumn{1}{c|}{} & & \multicolumn{1}{c}{} &
\end{tabular}

Keterangan:

$\mathrm{X}_{\mathrm{ij}}=$ Baris ke $\mathrm{i}$, kolom ke $\mathrm{j}$ disebut sel matriks

$\mathrm{i}=$ Menyatakan baris, yakni 1, 2, 3

$\mathrm{j}=$ Menyatakan kolom, yakni 1, 2, 3, 4, 5, 6

$\sum \quad=$ Jumlah

\section{Metode Analisis Data}

Metode analisis data yang digunakan adalah analisis kuantitatif dengan cara menghitung Chi Kuadrat $\left(X^{2}\right)$ dengan rumus:

$$
X^{2}=\sum_{i=1}^{k}\left[\frac{\left(f_{0-} f_{e}\right)^{2}}{f_{e}}\right]
$$

dimana:

$\mathrm{f}_{\mathrm{o}} \quad=$ Frekuensi Observasi

$\mathrm{f}_{\mathrm{e}}=$ Frekuensi yang Diharapkan

$\mathrm{k}=$ Banyaknya Sel dalam Matriks (Tabel)

\section{Analisis Hipotesis}

Untuk membuktikan hipotesis dengan cara menghitung nilai $X_{\text {hitung }}^{2}$ dan kemudian dibandingkan dengan nilai $X_{\text {tabel }}^{2}$ dengan kriteria penerimaan hipotesis sebagai berikut:

$\mathrm{X}^{2}$ hitung

$\mathrm{H}_{0}$ diterima, jika $\mathrm{X}^{2}{ }_{\text {hitung }}<\mathrm{X}^{2}$ tabel

$\mathrm{H}_{\mathrm{a}}$ diterima, jika $\mathrm{X}^{2}{ }_{\text {hitung }}>\mathrm{X}^{2}$ tabel 


\section{HASIL DAN PEMBAHASAN}

\section{Data Penelitian}

Data penelitian yang diperoleh dari Badan Pusat Statistik tahun 2014 disajikan sebagai berikut ini:

Tabel 2. Data Jumlah Orang Miskin di DKI Jakarta Tahun 2014

\begin{tabular}{clr}
\hline No. & \multicolumn{1}{c}{ Daerah } & Jumlah Orang Miskin \\
\hline \hline 1. & Kepulauan Seribu (KS) & 25.000 orang \\
2. & Jakarta Barat (JB) & 83.000 orang \\
3. & Jakarta Timur (JT) & 86.000 orang \\
4. & Jakarta Pusat (JP) & 33.600 orang \\
5. & Jakarta Selatan (JS) & 74.600 orang \\
6. & Jakarta Utara (JU) & 90.900 orang \\
\hline \multicolumn{2}{c}{ Jumlah }
\end{tabular}

Dari data tersebut di atas tampak prosentase penduduk miskin di DKI Jakarta sekitar 3,70 persen. Garis kemiskinan (Rp/kapita/bulan) Rp. 363.450/orang/bulan, artinya seorang yang pendapatannya lebih besar daripada garis kemiskinan itu dianggap tidak miskin.

Tabel 3. Data Tingkat Pendidikan Penduduk di DKI Jakarta

\begin{tabular}{|l|c|}
\hline Tingkat Pendidikan & $\mathbf{( \% )}$ \\
\hline < SD & $3 \%$ \\
\hline Tamat SD / SMP & $80 \%$ \\
\hline Tamat SMA + & $39 \%$ \\
\hline
\end{tabular}

Sumber : BPS 2014 setelah diolah.

\section{Analisis Data Penelitian}

Analisis data dilakukan dengan menggunakan analisis Chi Kuadrat dengan tabel kontingensi untuk melihat pengaruh Tingkat Pendidikan terhadap Kemiskinan di DKI Jakarat.

Tabel 4. Tabel Kontingensi

\begin{tabular}{|c|c|c|c|c|c|c|c|}
\hline \multirow{2}{*}{ Pendidikan } & \multirow{2}{*}{ KS } & JB & JT & JP & JS & JU & $\sum$ \\
\hline LSD & 3 & 10 & 6 & 11 & 8 & 25 & 63 \\
\hline Tamat SD / SMP & $(12,3)$ & $(10,2)$ & $(10,1)$ & $(10,1)$ & $(10,3)$ & $(10,1)$ & \\
\hline & 80 & 65 & 53 & 58 & 52 & 45 & 353 \\
\hline Tamat SMA + & $(69)$ & $(57)$ & $(38)$ & $(56,5)$ & $(34,1)$ & $(56,5)$ & \\
\hline & 39 & 26 & 41 & 31 & 42 & 30 & 209 \\
\hline$\sum$ & $(41)$ & $(8,7)$ & $(13,7)$ & $(10,4)$ & $(34,1)$ & $(33,4)$ & \\
\hline & 122 & 101 & 100 & 100 & 102 & 100 & 625 \\
\hline
\end{tabular}

Sumber : Hasil olahan peneliti 
Berdasarkan data pada tabel 4 (tabel Kontingensi) diperoleh nilai $X^{2}$ hitung sebesar 125,80 dan nilai $\mathrm{X}_{\text {tabel }}^{2}$ sebesar 18,31 dengan tingkat $\alpha$ sebesar 5\%. Dikarenakan nilai $\quad \mathrm{X}^{2}$ hitung $>\mathrm{X}^{2}$ tabel $(125,80>18,31)$, maka $\mathrm{H}_{0}$ ditolak dan $\mathrm{H}_{\mathrm{a}}$ diterima yang berarti terdapat pengaruh pendidikan terhadap tingkat kemiskinan di DKI.

\section{Pembahasan}

Berdasarkan hasil analisis menunjukan bahwa pendidikan berpengaruh pada tingkat kemiskinan di daerah DKI Jakarta dengan nilai $X^{2}{ }_{\text {hitung }}>X_{\text {tabel }}^{2}(125,80>$ 18,31). Dengan pendidikan yang rendah masyarakat akan sulit mendapatkan pekerjaan, sehingga mereka tidak akan mempunyai penghasilan dan akhirnya mereka menjadi miskin. Begitu pula sebaliknya, dengan pendidikan yang tinggi masyarakat akan mudah mendapatkan pekerjaan dengan upah yang layak yang meningkatkan kesejahteraan mereka, sehingga tingkat kemiskinan menjadi turun.

Hasil ini sejalan dengan hasil penelitian sebelumnya yang dilakukan oleh Aksentijevic (2006), Ukwuezze (2014), Zakharia (2006) dan Capra (2009) yang menyimpulkan bahwa tingkat pendidikan memiliki pengaruh terhadap jumlah penduduk miskin.

Selain itu hasil penelitian ini juga sesuai dengan teori yang dikemukakan oleh Bloom (2006) yang menyatakan bahwa pendidikan mampu memperbaiki kesejahteraan dan mengurangi kemiskinan. Serta sesuai juga dengan teori yang dikemukakan Arsyad (2010) yang menyatakan bahwa pendidikan memiliki peran penting dalam mengurangi kemiskinan di suatu negara baik secara langsung maupun tidak langsung. Selain sesuai dengan kedua teori tersebut, hasil penelitian ini juga sesuai dengan teori yang dikemukan oleh Dejanvry dan Sadoulet dalam Kokila (2000) yang menyatakan bahwa pendidikan mengurangi ketimpangan dan kemiskinan secara langsung, yaitu: dengan meningkatkan produktivitas bagi golongan miskin, memperbaiki kesempatan mereka untuk memperoleh pekerjaan dengan upah yang lebih baik.

Berbicara tentang kemiskinan, terdapat banyak sebab yang dapat membuat seseorang menjadi miskin, terutama jika dilihat dari pandangan hidup dan sikap terhadap pekerjaan. Ada seseorang atau suatu golongan yang berpandangan bahwa untuk apa kaya di dunia kalau nantinya akan tidak masuk surga, jadi yang penting di akhirat kelak masuk surga. Gaya hidup juga dapat menyebabkan seseorang menjadi miskin, misalnya gaya hidup yang boros. Sifat pemalas dapat juga menimbulkan kemiskinan, dimana seseorang malas bekerja sehingga dia tidak dapat mencukupi kebutuhan hidupnya.

Selain dari faktor pendidikan, pandangan hidup,dan gaya hidup tersebut di atas, masih ada faktor-faktor lain yang menyebabkan seseorang menjadi miskin, antara lain : tingkat upah yang rendah, sedikitnya lapangan kerja, meningkatnya harga-harga barang, dan sebagainya. 


\section{E. SIMPULAN}

Tingkat pendidikan sangat berpengaruh terhadap tingkat kemiskinan di daerah DKI Jakarta. Hal ini ditunjukan dari hasil analisis hipotesi dimana nilai $X^{2}{ }_{\text {hitung }}>X_{\text {tabel }}{ }(125,80>18,31)$ dengan $\alpha$ sebesar 5\%. Jadi semakin rendah tingkat pendidikan maka semakin tinggi tingkat kemiskinan, begitu pula sebaliknya semakin tinggi tingkat pendidik maka semakin rendah tingkat kemiskinan.

Disamping dipengaruhi oleh tingkat pendidikan, tingkat kemiskinan juga dipengaruhi oleh kurangnya kesempatan kerja, tingkat upah yang rendah, pandangan hidup, gaya hidup, dan sebagainya.

\section{DAFTAR PUSTAKA}

Aksentijevic, Nada Karaman; Bogovic, Nada Denona and Jezic, Zoran. (2006), Education, Poverty and Income Inequality in the Republik of Croatia. Zb rad Ekon Fak Rij.

Arsyad, L. (2010), Ekonomi Mikro. Yogyakarta: BPFE Universitas Gajah Mada.

Badan Pusat Statistik. (2014), Data Kependudukan DKI Jakarta Tahun 2014.

Bloom, David; Canning, David and Chan, Kevin. (2006), Higher Education and Economic Development in Africa. Human Development Research, Vol. 5, No. 1, (PP: 25-90).

Capra, T. (2009), Poverty and Its Impact on Education. The Nea Higher Education Journal, Vol. 25, No. 1, (PP: 78-111).

Doshi, Kokila P. (2000), Inequality and Economic Growth, University of San Diego.

Gillis, Malcom. (2000), Economic of Development. New York: WW Norton \& Company Inc.

Hamid, Edy Suandi. (2012), Dinamika Ekonomi Indonesia . Yogyakarta: UII Press.

Ihsan, F. (2011), Perkembangan Peserta Didik. Jakarta: Rineka Cipta.

Kuncoro, M. (2006), Ekonomika Pembangunan: Teori, Masalah dan Kebijakan. Yogyakarta: UPP STIM YKPN

Latif, Abdul. (2007), Pendidikan Berbasis Nilai Kemasyarakatan. Bandung: Reflika Aditama.

Nurihsan, Juntika, (2007), Perkembangan Peserta Didik, Bandung : Sekolah Pasca Sarjana UPI

Renggapratiwi, A. (2009). Kemiskinan Dalam Perkembangan Kota Semarang: Karakteristik Dan Respon Kebijakan. Semarang : Universitas Diponegoro

Sugiyono. (2012), Metodologi Penelitian Bisnis. Bandung : Alfabeta. 
Suhardan, Dadang. (2012), Ekonomi dan Pembiayaan Pendidikan. Bandung: Alfabeta

Sukirno, Sadono. (2006), Pengantar Teori Makro Ekonomi. Jakarta: Raja Grafindo Persada.

Sukirno, Sadono. (2006), Ekonomi Pembangunan (Edisi Kedua). Jakarta: Kencana.

Todaro, Michael, P. dan Stephen C. Smith. (2003), Pembangunan Ekonomi Di Dunia Ketiga, Edisi Kedelapan, Jakarta: Erlangga.

Ukwueze, Ezebuilo; Emmanuel, Nwosu. (2014), Does Higher Education Reduce Poverty Among Youth in Nigeria. Asian Economic and Financial Review, Vol. 4, No. 1, (PP: 1-19).

Wan, Usman. (2004), Metode Kuantitatif. Jakarta: Universitas Terbuka.

Wan, Usman. (2016), Sepuluh Langkah dalam Menulis Skripsi, Tesis, Disertasi. Pascasarjana Universitas Indonesia Program Studi Pengkajian Ketahanan Nasional.

Wiratna, Suryadeni. (2014), Tabel Chi Kuadrat, Pustaka Baru Press, Yogyakarta.

Zakharia, Z. (2006), Education and Poverty in an International Context. Society for International Education Teacher College Columbia University, (PP: 15$35)$. 